\title{
A PRODUÇÃO DE SENTIDOS SOBRE OS IMIGRANTES REFUGIADOS SÍRIOS NO BRASIL NA TELENOVELA “ÓRFÃOS DA TERRA"
}

DANIELA JAKUBASZKO UNIVERSIDADE MUNICIPAL DE SÃO CAETANO DO SUL SÃO CAETANO DO SUL, SÃO PAULO, BRASIL DANIELA.JAKUBASZKO@PROF.USCS.EDU.BR

ANNA CAROLINA CICILINI UNIVERSIDADE MUNICIPAL DE SÃO CAETANO DO SUL SÃO CAETANO DO SUL, SÃO PAULO, BRASIL ANNA.CICILINI@ALU.USCS.EDU.BR

LETÍCIA GOUVEIA VERAS UNIVERSIDADE MUNICIPAL DE SÃO CAETANO DO SUL

SÃO CAETANO DO SUL, SÃO PAULO, BRASIL LETICIA.VERAS@ALU.USCS.EDU.BR 


\section{A PRODUÇÃO DE SENTIDOS SOBRE OS IMIGRANTES REFUGIADOS SÍRIOS NO BRASIL NA TELENOVELA “ÓRFÃOS DA TERRA”}

Resumo: Este artigo apresenta resultados de uma pesquisa cujo objetivo foi estudar a produção de sentidos e as ressonâncias dialógicas criadas a partir das representações de imigrantes refugiados sírios no Brasil na telenovela "Órfãos da Terra" (TV Globo, 2019) de Duca Rachid e Thelma Guedes. Concluiu-se que a ficção promoveu o debate sobre xenofobia, rompeu estereótipos e construiu imagens do País como nação acolhedora.

Palavras-chave: Telenovela brasileira, Gênero discursivo, Estereótipos e preconceitos, Xenofobia.

\section{LA PRODUCCIÓN DE SIGNIFICADOS SOBRE LOS INMIGRANTES RE- FUGIADOS SIRIOS EN BRASIL EN LA TELENOVELA "HUÉRFANOS DE SU TIERRA" (ÓRFÃOS DA TERRA)}

Resumen: Este artículo presenta los resultados de una investigación cuyo objetivo fue estudiar la producción de sentidos y las resonancias dialógicas creadas a partir de las representaciones de los inmigrantes sirios refugiados em Brasil en la telenovela "Huérfanos de su Tierra" (Órfãos da Terra, Globo, 2019). Se concluyó que la ficción promovió el debate sobre la xenofobia, rompió estereotipos y construyó imágenes del país como una nación acogedora.

Palabras clave: Telenovela brasileña, Género discursivo, Estereotipos y prejuicios, Xenofobia.

\section{THE PRODUCTION OF MEANINGS ABOUT SYRIAN REFUGEE IMMI-} GRANTS IN BRAZIL IN THE TELENOVELA “ORPHANS OF A NATION" (ÓRFÃOS DA TERRA)

Abstract: This article presentes the results of an investigation in which the objectives were to study the production of meanings and the dialogical resonances created from the representations of Syrian refugee immigrants in Brazil in the telenovela "Orphans of a Nation" (Órfãos da Terra, TV Globo, 2019). The conclusion shows that the telenovela observed promoted the debate on xenophobia, broke stereotypes and released images of the country as a welcoming nation.

Keywords: Brasilian telenovela, Discursive genre, Stereotypes and prejudices, Xenofobia.

\section{INTRODUÇÃO}

A telenovela é um dos produtos televisivos de maior audiência na TV 
aberta brasileira. Essa preferência de variados públicos persiste ao longo do tempo e torna a teledramaturgia um objeto de estudo privilegiado para a compreensão da cultura brasileira (HAMBURGER, 2005; JAKUBASZKO, 2008; BORELLI, 2001).

Há mais de 60 anos, a telenovela brasileira vem narrando as transformações da cultura brasileira e se modificando com ela. Formou vínculos com diversos temas de interesse público, é um espaço de debate e reflexão, além de entretenimento. Pode ser estudada como documento de época e lugar simbólico de memória coletiva (MOTTER, 2000-2001), porque entrelaça as suas narrativas com as memórias individuais e coletivas do público com o cotidiano dos espectadores e do país. Estudos (MOTTER, 2003; JAKUBASZKO, 2008; 2019) mostram como as telenovelas vêm contribuindo para a desconstrução de diversos estereótipos e preconceitos que circulam no cotidiano.

Vale perguntar: quais imagens a telenovela "Órfãos da Terra" divulga sobre os imigrantes refugiados sírios? Como elas dialogam com as demais manifestações discursivas sobre o tema? Aparece o histórico do Brasil com as imigrações? Que ressonâncias dialógicas geradas pela telenovela podemos captar na mídia e nos discursos cotidianos? Qual discurso a telenovela veicula sobre os imigrantes refugiados e a xenofobia? Essas foram as questões que nortearam o objetivo principal da pesquisa que realizamos: um estudo sobre a produção de sentidos e as ressonâncias dialógicas a partir das narrativas dos imigrantes refugiado sírios na telenovela "Órfãos da Terra" de Duca Rachid e Thelma Guedes (TV Globo, 18h, 2019).

Seguindo metodologia fundamentada numa perspectiva dialógica para o estudo da ficção audiovisual (JAKUBASZKO 2019), realizaram-se as seguintes etapas: (1) estudo e descrição da narrativa da telenovela, principalmente dos núcleos de imigrantes; (2) pesquisa de conteúdo e clipagem para o tema da imigração e a produção da novela; (3) levantamento e registro, não exaustivos, de possíveis ressonâncias dialógicas captadas e divulgadas pela mídia em geral; (4) análise qualitativa dos resultados obtidos.

Além da trama principal, algumas tramas paralelas com tematização (MOTTER e JAKUBASZKO, 2007) da imigração na atualidade e algumas cenas com forte teor pedagógico integraram a amostra para observação e análise. São exemplos a trajetória da personagem Faruk (Eduardo Mossri) que chega no final feliz em sua luta para revalidar o diploma de médico e a do brasileiro que documenta a história dos refugiados, o fotógrafo Bruno 
(Rodrigo Simas), que abandona o mundo do luxo para ser fotojornalista e denunciar as injustiças sociais. Além de ajudar os refugiados de várias formas, compõe par amoroso com Marie (Eli Ferreira), refugiada do Congo. Durante a trama produziu um documentário sobre as pessoas em situação de refúgio que foi ao ar no capítulo do dia 09 de maio de 2019. Neste artigo trataremos apenas dos protagonistas.

Vale destacar que, para investigar os sentidos produzidos sobre os imigrantes sírios na telenovela, supomos a existência de uma dimensão social (pedagógica) e uma dimensão poética (melodramática), entrelaçadas na construção ficcional (MOTTER e JAKUBASZKO, 2007). Nesta pesquisa colocamos ênfase na dimensão pedagógica, procurando observar o discurso (dimensão social) sobre os refugiados no Brasil que a emissora propaga por meio da dimensão poética da ficção: da construção dos núcleos dramáticos (COMPARATO, 2000) e arco narrativo das personagens (FIELD, 2001).

Neste artigo será apresentada a análise de alguns dos principais resultados em quatro tópicos: (2.1) os refugiados sírios no Brasil; (2.2) os refugiados sírios na telenovela; (2.3) as cenas de caráter pedagógico; e (2.4) ressonâncias dialógicas.

\section{ANÁlISE dOS RESULTADOS OBTIDOS}

\subsection{Os refugiados sírios no Brasil}

A decisão de se deslocar do seu lugar de origem para buscar uma vida nova e diferentes oportunidades é o que define um migrante, que se desloca no âmbito nacional, e o imigrante, no âmbito internacional. Entretanto, existem pessoas que são forçadas a se deslocarem de seu país por diversos motivos que inviabilizam a sua existência e ferem o seu direito humano à vida, estes são conhecidos como refugiados.

A condição de refugiado se dá quando um indivíduo sai de seu país de origem devido a conflitos armados, violação dos direitos humanos e perseguição a grupos por questões raciais, religiosas, políticas, entre outras, que ameaçam sua existência.

A Convenção das Nações Unidas relativa ao Estatuto dos Refugiados de 1951 define em seu artigo $1^{\circ}(A, 2)$ que o refugiado é toda pessoa que

[...] devido a fundados temores de perseguição por motivos de raça, religião, nacionalidade, por pertencer a determinado grupo social e por suas opiniões políticas, se encontre fora do país de sua 
nacionalidade e não possa ou, por causa dos ditos temores, não queira recorrer a proteção de tal país; ou que, carecendo de nacionalidade e estando, em consequência de tais acontecimentos, fora do país onde tivera sua residência habitual, não possa ou, por causa dos ditos temores, não queira a ele regressar.

Segundo dados da Agência da ONU para Refugiados 70,8 milhões de pessoas sentem necessidade de sair do seu local de origem; a cada minuto, 25 pessoas são deslocadas à força em decorrência de conflitos ou perseguições. Busca-se refúgio em outros países, e depende deles o acolhimento e reconhecimento do status de refugiado, e, ainda que minimamente, a garantia de direitos básicos que a todos deveriam estar assegurados (MOULIN, 2011).

ONGs, com destaque ao Alto Comissariado das Nações Unidas para Refugiados (doravante, ACNUR) e governos locais auxiliam na reintegração territorial e a destravar barreiras socioculturais, linguísticas e econômicas. $O$ asilo está assegurado na Declaração Universal dos Direitos Humanos (OEA, 1948) em seu artigo XIV:

1 - Todo homem, vítima de perseguição tem o direito de procurar e de gozar de asilo em outros países.

2 - Este direito não pode ser invocado em caso de perseguição legitimamente motivada por crimes de direito comum ou por atos contrários aos objetivos e princípios das Nações Unidas.

A condição de refugiado não é recente; muitas pessoas se deslocam de seu país de origem. Foi a partir do século 20 que os refugiados começaram a ser reconhecidos legalmente e a entrar na legislação (LACERDA, 2015, p. 101). A criação da ONU, ao fim da Segunda Guerra, é a instância que assegura a dignidade dos refugiados com a Declaração Universal dos Direitos Humanos, já que ultrapassa as barreiras territoriais e preconiza universalidade de direitos.

No Brasil, com a Convenção da ONU de 1951, foram implementados o Estatuto dos Refugiados e a Lei $n^{\circ}$ 9.474/97. Como consta no capítulo 2:

Art. $5^{\circ}$ : O refugiado gozará de direitos e estará sujeito aos deveres dos estrangeiros no Brasil, ao disposto nesta Lei, na Convenção sobre o Estatuto dos Refugiados de 1951 e no Protocolo sobre o 
Estatuto dos Refugiados de 1967, cabendo-lhe a obrigação de acatar as leis, regulamentos e providências destinados à manutenção da ordem pública.

Art. $6^{\circ}:$ O refugiado terá direito, nos termos da Convenção sobre o Estatuto dos Refugiados de 1951, a cédula de identidade comprobatória de sua condição jurídica, carteira de trabalho e documento de viagem.

Segundo dados do CONARE, Comitê Nacional para os Refugiados, foram reconhecidos, em 2018, 1.086 novos refugiados no Brasil, atingindo o total de 11.231 pessoas reconhecidas como refugiadas no país (DADOS..., [s.a.]). Dentre esse total, destaca-se a alta porcentagem de refugiados sírios, representando $36 \%$ do total dessa população, seguidos de congoleses (15\%) e angolanos (9\%).

A Síria sofre seu pior momento da história, por isso a busca por refúgio em outros países. A Guerra Civil se iniciou em março de 2011, com protestos populares, mas logo evoluiu para conflitos armados.

Na fronteira com Turquia, Iraque, Líbano, Israel e Jordânia, a Síria é comandada desde a década de 70 pela família al-Assad e desde 2000 por Bashar al-Assad. Tudo se iniciou com a onda de protestos motivados pelos países árabes a partir de 2010/2011, movimento conhecido como Primavera Árabe. Reivindicava-se reformas políticas, melhor qualidade de vida e mais democracia. Os governos responderam com repressão e grupos de cidadãos se armaram para lutar contra as tropas. A guerra começou quando os grupos protestantes se juntaram aos militares desertores e formaram milícias armadas para revidar a repressão. Em resposta, Bashar al-Assad impôs mais repressão ainda, espalhando a violência por todo o país.

Outros grupos rebeldes foram surgindo a partir de interesses em comum, tornando a guerra não só política, mas também religiosa. De um lado, o ditador Bashar al-Assad permanece no poder, apoiado por Rússia, Irã e milícias xiitas; de outro, os grupos rebeldes, entre eles o ELS, o Jaysh al Islam e o Ahrar al Sham, e no meio disso o Estado Islâmico, que se aproveita da situação para conquistar territórios sírios.

A Síria encontra-se fragmentada entre os vários grupos existentes, o conflito gera uma indefinição quanto ao fim da guerra e a tão sonhada paz. Segundo dados do observatório Sírio de Direitos Humanos, esta Guerra Civil já foi responsável por mais de 500 mil mortes e levou mais da metade da po- 
pulação, cerca de 11 milhões de sírios, a se refugiar em outros países (MAIS..., 2018). Além de viverem em constante ameaça, a fuga para outro local é perigosa e feita em péssimas condições, muitos perdem a vida no caminho. Ao chegar em nova terra, ao invés de acolhimento, precisam lidar com diversos problemas, como a ilegalidade no país, e mesmo que conquistem seus direitos, as dificuldades culturais e econômicas, além do próprio xenofobismo. Mesmo que garantido por lei, o direito dos refugiados é frágil.

O Brasil recebe muitos sírios, o que é explicado pelas políticas que facilitam a emissão de visto para tal população, como a Resolução Normativa n. ${ }^{\circ} 17 / 2013$.

Em outubro de 2015, o Brasil assinou um documento de cooperação com ACNUR para orientar os consulados brasileiros sobre o processo de documentação e emissão de vistos para imigrantes e refugiados. Não há nenhum tipo de auxílio do governo, como ocorre na Europa. Aqui, precisam arcar com a própria sorte ou auxílio de pessoas e ONGs.

Os sírios quando chegam no Brasil se deparam com barreiras da língua e da falta de assistência, dificuldades financeiras e de encontrar moradia. Um refugiado tem carteira de trabalho e os mesmos direitos que um trabalhador brasileiro, porém, mesmo com formação, os diplomas não são reconhecidos no Brasil, o processo burocrático de validação é longo e caro. Como saída, muitos optam por montar barracas de comidas típicas sírias como forma de ganhar a vida. A culinária é a principal fonte de renda de muitos dos sírios, como bem foi representado na novela.

A xenofobia é definida pela ACNUR como sendo as "Atitudes, preconceitos e comportamentos que rejeitam, excluem e difamam pessoas, com base na percepção de que eles são estranhos ou estrangeiros à comunidade, sociedade ou identidade nacional". São diversas as discriminações praticadas contra refugiados: xingamentos para sua pessoa ou cultura, recusa na contratação em postos de trabalho, inúmeras formas de exclusão por violência psicológica e moral e até por violência física.

Um caso evidente de xenofobia foi o ataque ao bar palestino localizado no Bairro do Bixiga, em São Paulo, por meio de garrafas e spray de pimenta lançados na porta do estabelecimento. A assessoria diz que não foi "coincidência", visto que o estabelecimento já vinha sofrendo ataques de ódio e intolerância (O ATAQUE... 2019).

Outro caso foi registrado no vídeo que mostra um refugiado sírio sendo 
agredido por um GCM de São Paulo'. Foi alvo de agressões verbais e físicas. O GCM fazia uma desocupação de área pública, onde morava o sírio, que trabalhava num restaurante.

A agressão física xenofóbica é crime definido pela Lei $n^{\circ} 7.716$, de janeiro de 1989 , cujo artigo $1^{\circ}$ garante que "serão punidos, na forma desta Lei, os crimes resultantes de discriminação ou preconceito de raça, cor, etnia, religião ou procedência nacional”. As ofensas verbais podem ser caracterizadas como crime de injúria. A xenofobia é a grande barreira, a mais difícil de combater.

A telenovela mostra algumas manifestações de xenofobia e veicula um discurso contra os preconceitos. Se para o cidadão comum é difícil compreender as articulações políticas e o contexto histórico que provocou todos esses conflitos e deslocamentos, por meio da ficção, pode-se compreender ao menos o drama que as pessoas passam quando suas vidas e seu futuro são capturados pelos acontecimentos políticos que definem a história das nações e os destinos de seus cidadãos.

\subsection{Os refugiados sírios na telenovela}

A telenovela Órfãos da Terra foi produzida e exibida pela Rede Globo entre 2 de abril de 2019 e 27 de setembro de 2019, escrita por Duca Rachid e Thelma Guedes, dirigida por Pedro Peregrino, Alexandre Macedo, Bruno Safadi e Lúcio Tavares.

A direção geral é de André Câmara e a direção artística de Gustavo Fernández.

No Brasil, Rania Anssarah Nasser (Eliane Giardini)é a matriarca da família. Vinda da Síria, casou-se com Miguel Nasser (Paulo Betti), descendente de sírios, com quem teve três filhas, já adultas no início da trama: Zuleika (Emanuelle Araújo), Camila (Anaju Dorigon) e Aline (Simone Gutierrez).

Ela esconde um segredo que será revelado ao longo da história e dará interseccionalidade aos núcleos: ser mãe de Soraia Abdallah (Letícia Sabatella). Quando jovem fora obrigada a deixar a filha no Líbano com outra família após ter sido abandonada por seu namorado da época. A menina é levada para o Líbano e vendida para Aziz Abdallah (Herson Capri), um poderoso

1 Vídeo mostra refugiado sírio sendo agredido pela GCM de São Paulo. R7, São Paulo, 07 de jul. de 2019. Disponível em:<https://noticias.r7.com/sao-paulo/video-mostra-refugiado-sirio-sendo-agredido-pela-gcm-de-sao-paulo-17072018> Acesso em: 10.12.2019. 
sheik. Ela se torna sua primeira esposa, com quem tem sua filha dileta, Dalila Abdallah (Alice Wegmann), que, como o pai, é arrogante e cruel. Ele não teve um filho homem, então a prepara para comandar tudo.

As histórias começam a se misturar quando o sheik Aziz se apaixona por Laila Faiek (Julia Dalavia) que se encontra num campo de refugiados no Líbano após sua família perder tudo num bombardeio na Síria. Ela está com a família a caminho do Brasil, para encontrar a prima Rania. Mas seu irmão Khaléd (Rodrigo Vidal) está muito doente, então Laila aceita se casar com o sheik para salvar o irmão. Os pais, Elias Faiek (Marco Ricca) e Missade (Ana Cecília Costa), permitem, mas cheios de tristeza, culpa e vergonha, perdidos com a destruição que a guerra civil na Síria causou em suas vidas.

Khaléd acaba morrendo na mesa de cirurgia e Laila recebe ajuda da primeira esposa de Aziz, a filha abandonada por Rania, para fugir antes do casamento ser consumado. O sheik coloca seus capangas atrás dela e sua família. Entre eles Jamil (Renato Góes), seu afilhado de confiança e noivo de Dalila. Por obra da ironia dramática, Jamil havia visto e trocado algumas palavras com Laila no campo de refugiados. Foi paixão à primeira vista de ambos os lados. O desespero tomou conta de Jamil quando soube que a moça que procurava para casar com o padrinho era a sua amada. Jamil, que havia assumido e pagado por um crime cometido por Aziz, tinha a sua vida e seu destino nas mãos dele. Foi mandado para o Brasil para resgatar Laila. Ele aceita a viagem, mas com a intenção de fugir junto com ela.

Ao descobrir, sedento em punir seu afilhado e Laila pela traição, Aziz vai para São Paulo atrás dos dois e é morto em circunstâncias misteriosas. Então sua filha Dalila decide vingar a morte do pai e separar o casal, por vê-los como responsáveis e por Jamil ter se recusado a casar com ela conforme sua vontade e do pai.

Segue-se o melodrama em que a vilã comete as ações mais cruéis para tentar impedir a felicidade do casal. Evidentemente seu final é trágico, e quando desmascarada resolve pelo suicídio. Uma de suas maldades era fomentar o discurso de ódio e a xenofobia para atingir Laila e sua família.

Como característico do gênero, o melodrama se entrelaça às questões do cotidiano, produzindo um discurso na direção da quebra de estereótipos e preconceitos com os imigrantes e refugiados; a dimensão pedagógica (MOTTER e JAKUBASZKO 2007; JAKUBASZKO, 2019) enfatiza a empatia e fomenta a convivência harmônica com as diferenças culturais. Exalta a face acolhedora do Brasil, que assume sua história repleta de ciclos de imigrações, 
pessoas que vieram de diferentes lugares do mundo recomeçar suas vidas após a destruição de seus lugares de origem ou grupos de pertença.

Os primeiros capítulos emocionam ao mostrar cenas desoladoras de uma cidade bombardeada; o desespero de perder pessoas e todos os bens; cenas da travessia a pé para o Líbano, a estadia em campos de refugiados e a travessia pelo mar, cujas cenas com forte dramaticidade, em que passam por um ataque em alto mar e naufrágio, e fazem referência ao menino refugiado sírio Alan Kurdi que chocou o mundo ao ser encontrado na praia (A HISTÓRIA..., 2015).

Imagem 1: Frame de Órfãos da Terra, capítulo de 05.04.19, 27’17”.

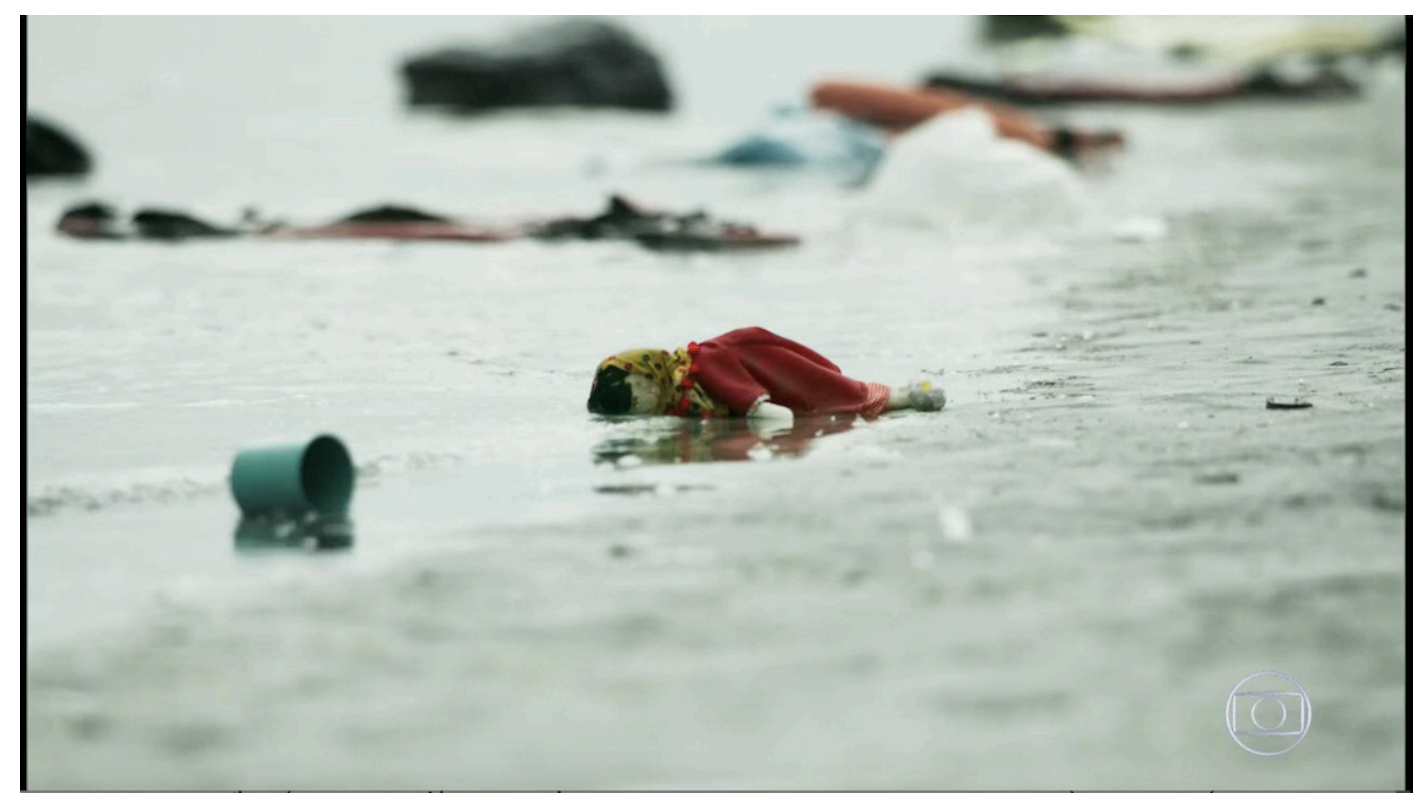

Fonte: Globoplay.

A emissora teve apoio técnico da Acnur para fazer, em Santa Cruz, na Zona Oeste do Rio de Janeiro, uma réplica de um campo de refugiados na Jordânia. O terreno 15 mil metros quadrados foi ('Órfãos da terra', próxima novela das $18 \mathrm{~h}, 2019)$ espaço de importantes pontos de virada na trama.

Os primeiros capítulos fornecem maior elementos sobre a cultura e a situação por que passam os refugiados. Para além dos números e estatísticas que recebemos dos telejornais, das narrativas e imagens de uma Síria destruída, estão as experiências subjetivas, os dramas pessoais que cabem melhor na ficção e por isso comovem e ativam a empatia do espectador que vive tão longe de todos aqueles conflitos.

No primeiro capítulo de Órfãos da Terra logo de início é apresentada a cena de Elias Faiek, exercendo sua profissão como engenheiro em uma 
obra e recebendo a lição de sua esposa Missade que lembra da festa de aniversário de seu filho mais novo, Khaléd.

Ao retornar para casa o clima é de descontração em uma reunião de família, com danças, músicas e comida, quando Laila vai até a cozinha buscar mais vinho e é surpreendida pela invasão da residência por rebeldes, que, armados, os fazem de refém.

Quando levados a um terraço, todo o grupo começa a ouvir bombardeios e em seguida helicópteros sobrevoam a casa. Por um milésimo de segundo a protagonista consegue empurrar os pais e o irmão para dentro antes do local ser atingido.

Laila acorda em uma maca percebendo que foram todos soterrados com os destroços da casa e sai gritando pelas ruas atrás dos pais e do irmão, percebendo o cenário de destruição da guerra em sua cidade, Fardús. Quando finalmente os encontra percebe que seu irmão foi ferido. Seguem para um abrigo de ajuda humanitária, um galpão com muitas pessoas, enfileiradas para obter água, deitadas no chão. Ainda machucados e com as roupas do corpo, discutem sobre atravessar a fronteira do Líbano a pé, irem para a Europa e de lá para o Brasil, Laila revela que os transportes não estão mais funcionando e sugere irem para a casa da prima Rânia, mas Missade fica relutante quanto a deixar seu país, sua cultura e seu povo para trás, até concluírem que é a única opção.

Ao revisitarem sua casa, acham um cofre com o dinheiro necessário para viajar para a Europa e pagar o tratamento do filho caçula. Deixam o local com risco de desabamento às pressas. A cena evidencia o drama de deixar tudo para trás e seguir apenas com a roupa do corpo. Seguem a pé com um grupo durante seis dias para um campo de refugiados em Beirute, no Líbano.

Paralelamente, em outro núcleo, o Shake Aziz Abdallah manda seus capangas, inclusive seu braço direito, Jamil Zarif, a este campo buscar trabalhadores, quando então avista Laila e resolve comprá-la de seu pai. Ao mesmo tempo, a alguns metros de distância, Laila e Jamil se encontram e acontece a paixão à primeira vista.

O estado de saúde de Khaléd vai piorando até que a família resolve ir ao hospital na cidade e descobre que ele necessita de uma cirurgia muito cara. Após perceber que o pouco de dinheiro que restava fora roubado, a jovem se vê sem alternativa além de se deixar comprar pelo Sheik Aziz, que promete pagar todos os custos médicos. 
Chega o dia do casamento e a jovem descobre que seu irmão faleceu, sendo assim, se vê livre para fugir antes que esse seja consumado. Aziz persegue a moça e manda seus capangas, inclusive o apaixonado Jamil, atrás dela. Depois de se esconder num campo de refugiados longe da cidade, Laila consegue reencontrar seus pais que conseguem um bote até a Europa por 1200 euros por pessoa, um valor exorbitante pelas condições precárias do transporte, o negociante pressiona Elias: o barco está cheio e só restaram 3 vagas. Era a última chance de a família vir ao Brasil e também fugir do Sheik.

Apesar de saberem dos riscos da embarcação, a família Faiek se choca ao perceber que o bote não passa de um barquinho inflável, extremamente frágil, onde ficarão dias até chegar na Grécia. Podem levar apenas uma mochila. Após receberem coletes salva-vidas, partem dois botes rumo a Europa, mas no meio da noite, a gasolina acaba. Os navegantes começam a remar. Quando avistam um barco maior começam a gritar por ajuda. Passados alguns segundos, tiros são disparados contra o bote que começa a afundar, levando com ele todos os tripulantes. Muitos não sabem nadar e acabam morrendo afogados, suas poucas coisas também são perdidas no meio do mar e da confusão, muitos gritos de socorro são ouvidos. Laila tenta achar os pais e por sorte, depois de algumas horas, consegue achar Elias, se seguram em um pedaço do bote ainda flutuante e gritam por Missade. Passam a noite em alto mar e no dia seguinte são resgatados por um bote da ONU, que os levam para um barco maior, prestando acompanhamento médico, além de água e comida. Laila, ao observar os novos náufragos que chegam o tempo todo, reencontra a mãe. Ao desembarcarem num campo de refugiados na Grécia, Elias aparece com boas novas: conseguiu trocar serviços por transporte para os três num navio turístico com destino ao Brasil, onde Laila reencontrará seu grande amor Jamil Zarif.

\subsection{As cenas de caráter pedagógico}

Ao longo da história, ficam as cenas que nos fazem refletir sobre como os brasileiros recebem refugiados e propõem romper preconceitos. Algumas cenas mostram os diversos desafios: as dificuldades com a língua (capítulo de 28/06/2019), com a busca de um emprego, com as diferenças culturais, com as ONGs que ajudam no trabalho de recepção e inclusão dos estrangeiros na sociedade brasileira. Há referências a refugiados em Roraima (capítulo de 06/08/2019), refugiados venezuelanos no Brasil (capítulo de 15/08/2019), 
CADERNOS DE COMUNICAÇÃO

UNIVERSIDADE FEDERAL DE SANTA MARIA

as dificuldades na validação de diplomas (capítulos de 19 e 23/08/2019), os problemas e traumas psicológicos que refugiados desenvolvem (capítulos de 05 e 29/06/2019), discursos em diferentes famílias contra a xenofobia (ver exemplos nos capítulos de 06 e 07/06/2019 e de 27/09/2019), ataques xenofóbicos (capítulos de 8 e 14/05/2019 e de 23/07/2019). São confirmações de que a telenovela assume um discurso contra a xenofobia e a favor do convívio com as diferenças. São vários os exemplos, mas um deles concretiza situações que lemos nos jornais sobre ataques xenofóbicos que ocorrem com certa frequência em pontos de trabalho dos imigrantes sírios, bolivianos, haitianos, entre outros. Escolhemos para este artigo uma sequência do capítulo de 06 de junho de 2019, quando Laila e Missade estão na barraquinha vendendo comidas típicas. Segue a transcrição:

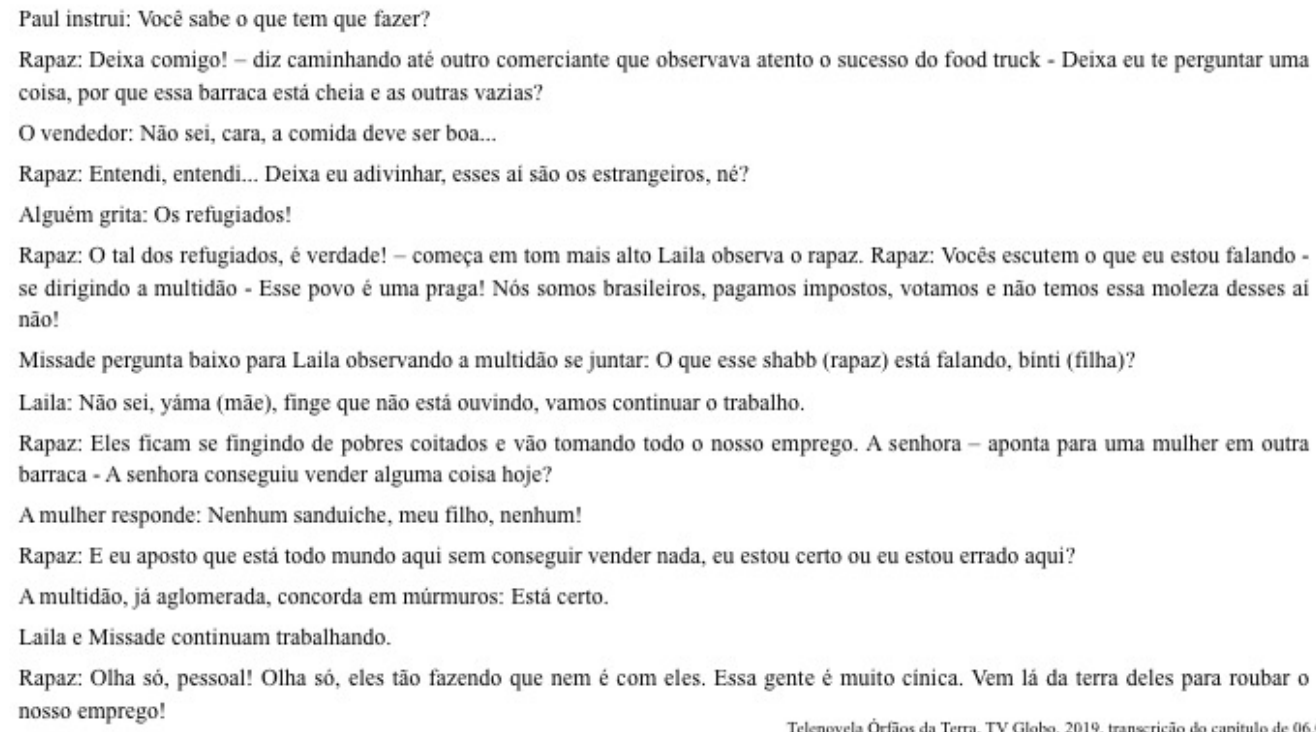

A multidão concorda e o rapaz continua: Vocês voltem para terra de vocês! Nós não queremos vocês aqui! Missade e Laila se olham.

A sequência continua no capitulo de 07 de junho de 2019.

Rapaz: Fora daqui, voltem para casa de vocês! Vocês estão roubando o nosso emprego, vocês vieram do pais de vocês, acabaram com tudo por lá e agora querem tirar o que é nosso!

Laila: Você não sabe, a gente não quer roubar nada de ninguém não, a gente quer trabalhar aqui, viver em paz!

O rapaz começa a endossar vaias e é acompanhado pela multidão.

Laila: Me ouve, pelo menos ouve o que eu estou dizendo! Nós saimos do nosso país por causa de uma guerra. Isso vocês não sabem o que é, vocês não sabem o que é ter que deixar tudo para trás: a casa, os amigos, a familia, tudo! A única coisa que a gente quer aqui é trabalhar em paz, è viver em paz!

Rapaz: Pessoal, pessoal, vocês não vão cair no papo furado dessa refugiadazinha! Gente, eles só querem se dar bem em cima da gente. A multidão concorda.

Laila: A gente não quer se dar bem, nós somos amigos.

Rapaz: Se vocês são amigos da gente, a gente vai comer de graça na sua barraca. - Fala incentivando a multidão a atacar a barraca, que rouba as comidas e os equipamentos.

Laila liga para o padre que aconselha: Não, Laila, não reaja, não faça nada! Eu também estou indo para ai agora mesmo! Um funcionário do Instituto Boas Vindas liga para o delegado Almeida. 
A multidão concorda e o rapaz continua: Vocês voltem para terra de vocês! Nós não queremos vocềs aqui!

Missade e Laila se olham

A sequência continua no capitulo de 07 de junho de 2019.

Rapaz: Fora daqui, voltem para casa de vocês! Vocês estão roubando o nosso emprego, vocês vieram do pais de vocês, acabaram com tudo por lá e agora querem tirar o que é nosso!

Laila: Você não sabe, a gente não quer roubar nada de ninguém não, a gente quer trabalhar aqui, viver em paz!

O rapaz começa a endossar vaias e é acompanhado pela multidão.

Laila: Me ouve, pelo menos ouve o que eu estou dizendo! Nós saimos do nosso país por causa de uma guerra. Isso vocês não sabem o que é, vocês não sabem o que é ter que deixar tudo para trás: a casa, os amigos, a familia, tudo! A única coisa que a gente quer aqui é trabalhar em paz, é viver em paz!

Rapaz: Pessoal, pessoal, vocês não vão cair no papo furado dessa refugiadazinha! Gente, eles só querem se dar bem em cima da gente. A multidão concorda.

Laila: A gente não quer se dar bem, nós somos amigos.

Rapaz: Se vocês são amigos da gente, a gente vai comer de graça na sua barraca. - Fala incentivando a multidão a atacar a barraca, que rouba as comidas e os equipamentos.

Laila liga para o padre que aconselha: Não, Laila, não reaja, não faça nada! Eu também estou indo para ai agora mesmo! Um funcionário do Instituto Boas Vindas liga para o delegado Almeida.

\title{
2.4 Ressonâncias dialógicas
}

A telenovela é um gênero discursivo (BAKHTIN, 2006) que ancora sua realidade ficcional na realidade cotidiana do espectador. Na construção de toda nova produção há uma etapa longa de detalhada pesquisa para que elementos de caracterização, rotina e ambientação produzam verossimiIhança e realismo.

\begin{abstract}
A telenovela recorre à experiência de vida dos cidadãos brasileiros para ganhar em realismo e diálogo com a audiência e o cotidiano. Enquanto gênero propõe hibridações que se aproximam dos gêneros jornalísticos e documentário (JAKUBASZKO, 2019, p. 53).
\end{abstract}

Além do documentário feito pelo personagem Bruno, para produzir a telenovela "Órfãos da Terra", houve uma pesquisa profunda para diversos aspectos da cultura síria e da história da guerra. Na preparação do elenco, além de workshop com representantes sírios no Brasil, os atores tiveram aulas de danças e costumes típicos da cultura síria, além de contato com o idioma. Cada detalhe das cenas que exibiam a cultura síria contou com consultores especializados. Como por exemplo, na primeira cena da novela, a comemoração do aniversário, em que cantaram os "Parabéns a você" em sírio e as danças típicas de festas. Até mesmo pequenos detalhes foram pensados para representar a realidade síria, como o casamento, a utilização do hijab (lenço), a posição que entravam nas salas, entre outros. 
As imagens dos cinco capítulos que se passam no percurso entre Líbano, Síria e Grécia, foram filmadas no Rio de Janeiro, com adaptações para que se assemelhassem às condições geográficas destes locais. Foi encontrada uma locação na cidade que seguia os parâmetros sírios de construção. Foram recriadas, utilizando técnicas de $3 \mathrm{D}$, as casas ao entorno, para produzir o efeito especial de explosão no bombardeio, simulando uma situação real da guerra. Outro cenário impactante foi o campo de refugiados, montado a partir de uma parceria com o ACNUR, importantes para mostrar como são os abrigos reais para refugiados. A figuração no abrigo foi composta por um elenco de descendentes e refugiados. $\mathrm{Na}$ abertura da novela, refugiados de diversos países se juntaram aos atores (ÓRFÃOS DA TERRA, PRÓXIMA..., 2019).

Para a história gerar impactos significativos nos espectadores e para o debate social, não basta apenas um bom enredo, tem de haver uma identificação com as personagens (COMPARATO, 2000) e o alinhamento entre o texto e as imagens mostradas, além de mostrar os dramas que refugiados enfrentam com base em pesquisas e relatos. $O$ trabalho foi feito meticulosamente pelas equipes técnicas e de produção desta telenovela. Desta maneira, a ficção pôde gerar uma identificação e os espectadores puderam colocar-se no lugar das personagens e humanizar sua percepção sobre os refugiados. De acordo com a plataforma da Google, Google Trends, a pesquisa pelo termo "refugiado" cresceu juntamente com a exibição da telenovela ${ }^{2}$, evidenciando o interesse sobre o tema.

No Brasil, a exibição do último capítulo movimentou a internet e entrou para os assuntos mais comentados do momento na rede social Twitter. A repercussão, no geral, foi positiva, mas alguns comentários ressaltavam uma avaliação negativa da finalização de alguns núcleos da trama. O discurso final da protagonista Laila (Julia Dalavia), que foi bastante elogiado pelos internautas na rede social, sintetiza o ponto de vista da ficção:

[...] Que o Brasil continue sendo esse país acolhedor, com pessoas que praticam a empatia, a solidariedade, o respeito às diferenças e o amor, que esse país que é um grande caldeirão de raças inspire o mundo. Que não existam mais fronteiras fechadas, crianças sem pais, barcos sem portos para atracar, bombas que matam e incên-

2 ÓRFÃOS da Terra, Refugiados, Google Trends. 2019. Disponível em: https://trends. google.com.br/trends/explore?date=2019-01-01\%202019-12-31\&geo=BR\&q=Orfãos\%20 da\%20Terra,Refugiados. Acesso em: 20 jun. 2020. 
dios que destroem memórias e culturas em nome da ganância e da intolerância. Que não existam mais gases lacrimogênios e sprays de pimenta, que ardem, nos cegam e nos impedem de enxergar o outro. Que não se faça noite em pleno dia. Que angolanos, curdos, ciganos, bolivianos, tibetanos, palestinos, congoleses, indígenas, filipinos, sírios, cristãos, judeus, muçulmanos de Mianmar e de todo mundo deixem de ser órfãos e possam ser todos filhos dessa terra (FIM..., 2019).

A telenovela "Órfãos da Terra" trouxe para o espectador o diálogo com as memórias do passado e as experiências cotidianas atuais de imigrantes e de descendentes de imigrantes. A novela evidenciou que o Brasil é uma nação que se formou a partir da contribuição de diferentes povos e culturas, e que este momento em que novos fluxos migratórios acontecem entre nações e continentes pode ser mais uma oportunidade de receber novos costumes. Para trabalhar e discutir o tema da imigração e xenofobia, a telenovela ativou as memórias dos grupos sociais de diferentes origens e suas histórias de chegada ao Brasil e como puderam conviver aqui harmonicamente apesar das diferenças. Um dos discursos abraçados pela novela é o de que há espaço para todos nessa terra chamada Brasil. Junto com as memórias de indivíduos, famílias e comunidades, ativam-se os afetos capazes de permitir a empatia e a caracterização da Nação como um lugar acolhedor, no qual as pessoas chegam de suas terras devastadas com seus sonhos destruídos e podem encontrar apoio e cooperação para reconstruir suas vidas apesar da dor da perda.

Foi possível observar que a telenovela "Órfãos da Terra" obteve sucesso de público equivalente de suas antecessoras, recebendo muitos elogios de crítica, se tornando fenômeno de exportação, licenciada para mais de 50 países (CASTRO, 2020), porque seu tema principal encontra ressonância no presente histórico não apenas nacional, como também global.

Por mais que se questione o vigor e a adequação do gênero teledramatúrgico, que se verifiquem oscilações e perdas de audiência, ele se reinventa enquanto gênero e formato (...) e se mantém forte enquanto discurso capaz de captar e expressar os temas e conflitos socioculturais brasileiros em tempos de globalização (...). A audiência ainda se reconhece, se identifica e se atualiza com as histórias contadas, e agora não apenas a audiência brasileira. Totalmente integrada à nossa cultura, a telenovela acumula e produz memória, conhecimento, participa dos diálogos sociais dando visibilidade a determinados temas e contribuindo para a (re) 
formulação de consensos. Seu estudo é indispensável (JAKUBASZKO, 2019, p. 26).

No caso de Órfãos da Terra, ainda que não tenha se tornado uma novela campeã de audiência, se estabilizou como produto que faz mediação importante ao tematizar as histórias de refugiados, ativando boa repercussão internacional. Duca Rachid e Telma Guedes foram até Londres receber o prêmio que Órfãos da Terra recebeu na categoria de melhor novela no Rose d'Or Awards. A premiação existe há mais de 60 anos e foi a primeira vez que uma novela brasileira ganha o prêmio. "Isso só prova a qualidade do tema e a importância a um nível mundial. É muito emocionante!", relata Duca a uma entrevista para o Gshow, portal de entretenimento da Globo. Segundo as autoras, foi uma oportunidade de colocar em pauta as histórias de refugiados, que "É um tema muito sensível e atual” ('ÓRFÃOS DA TERRA' VENCE..., 2019).

A telenovela ganhou o mais importante da TV sul-coreana, o Seoul Drama Awards, na categoria Grand prize, atribuído de acordo com a originalidade e relevância da produção ('ÓRFÃOS DA TERRA' GANHA..., 2020).

\section{CONSIDERAÇÕES FINAIS}

A maneira como a telenovela convida toda população a uma reflexão profunda e humanitária dos reais motivos pelos quais as pessoas migram, contrapondo o senso comum utilizado como justificativa para declarações preconceituosas pode ser observada em vários capítulos dessa obra. Durante a pesquisa procuramos informações sobre fluxos migratórios e sobre as dificuldades que os refugiados enfrentam. Selecionamos cenas e trajetórias de personagens para análise. Ficção e realidade se entrelaçam nas imagens e narrativas das personagens para que espectadores possam ir além de seus preconceitos.

A telenovela "Órfãos da Terra" dá visibilidade aos aspectos subjetivos de um tema anteriormente apresentado pelos jornais e revistas num tom formal e estatístico. Agora, o tema dos refugiados sírios ganhou vida através da telenovela que além de demonstrar num sentido prático, com situações cotidianas, os dilemas vividos pelas pessoas que chegam no país, aprofundou de maneira didática os debates sobre a xenofobia.

\section{REFERÊNCIAS}


A HISTÓRIA POR trás da foto do menino sírio que chocou o mundo. BBC News Brasil. 03.09.2015. Disponível em https://www.bbc.com/portuguese/noticias/2015/09/150903_ aylan_historia_canada_fd Acesso em 02.02.2020

ACNUR - Alto Comissariado das Nações Unidas para Refugiados. (2004), "Declaração e plano de ação do México". Disponível em www.acnur.org/biblioteca/pdf/3453.pdf Acesso em: 8 de out. de 2019

BAKHTIN, M. Estética da criação verbal. São Paulo: Martins Fontes, 2006.

BORELLI, Silvia Helena Simões. Telenovelas brasileiras: balanços e perspectivas. São Paulo Perspec., São Paulo, v.15, n.3, p. 29-36, 2001.

BRASIL. Lei n 9474, de 22 de julho de 1997. Institui o Código Civil. Diário Oficial da União: Condição jurídica dos refugiados, Brasília, DF, 1997. Disponível em: http://www.planalto. gov.br/ccivil_03/LEIS/L9474.htm Acesso em: 5 de dez. de 2019.

BRASIL. Resolução Normativa n. 17 de 20 de setembro de 2013. Acesso em: 28 de nov. de 2019.

CASTRO, Daniel. Órfãos da Terra supera tropeço no Brasil e vira fenômeno de exportação da Globo... Notícias da TV- UOL, 19.05.2020. Disponível em https://noticiasdatv. uol.com.br/noticia/novelas/orfaos-da-terra-supera-tropeco-no-brasil-e-vira-fenomeno-de-exportacao-da-globo-36930?cpid=txt Acesso em 21.07.2020.

COMPARATO, D. Da criação ao roteiro. Rio de Janeiro: Rocco, 2000.

DADOS sobre refúgio no brasil. Acnur.org s/d. Disponível em https://www.acnur.org/portugues/dados-sobre-refugio/dados-sobre-refugio-no-brasil/Acesso em 02.02.2020

FIELD, S. Manual do Roteiro: os fundamentos do texto cinematográfico. Rio de Janeiro: Objetiva, 2001.

FIM de 'Órfãos da Terra' comove web com discurso de Laila e casamento de Fauze. Terra, 27 set. 2019. Disponível em: https://www.terra.com.br/diversao/gente/purepeople/fim-de-orfaos-da-terra-comove-web-com-discurso-de-laila-e-casamento-de-fauze,d5315d7bb2ddabbd105f4458f30of8c2bv8d5j47.html Acesso em: 20 jun. 2020.

HAMBURGER, E. O Brasil antenado. A sociedade da novela. Rio de Janeiro: Jorge Zahar Editor, 2005.

JAKUBASZKO, Daniela. Levantamento da presença de temas de importância social nas telenovelas brasileiras. Anais do XXXI Congresso Brasileiro de Ciências da Comunicação, UFRN, 2008.

JAKUBASZKO, Daniela. A representação de temas de interesse público na telenovela brasileira: uma perspectiva dialógica para o estudo da ficção audiovisual. Alexa Cultural: Embu das Artes-SP e EDUA: Manaus-AM, 2019.

LACERDA, Jan Marcel de Almeida Freitas; SILVA, Amanda Arruda de Souza e; NUNES, Rayanne Vieira Galvão. O caso dos refugiados sírios no Brasil e a Política Internacional Contemporânea. Revista de Estudos Internacionais, João Pessoa, v. 6, n. 2, p.100-116, 2015. Disponível em: https://www.revistadeestudosinternacionais.com/uepb/index.php/ rei/article/view/209/pdf. Acesso em: 27 de nov. de 2019. 
MAIS DE 500 mil pessoas morreram na guerra da Síria, diz ONG. Folha de S. Paulo, São Paulo, 12 de mar. de 2018. Disponível em: https://www1.folha.uol.com.br/mundo/2018/03/ mais-de-500-mil-pessoas-morreram-na-guerra-da-siria-diz-ong.shtml Acesso em: 9 de dez. de 2019.

MOTTER, Maria Lourdes. A Telenovela: Documento Histórico e Lugar de Memória. SP, 2000. 2326, no GT Telenovela e Sociedade, seção de 23.10.00. Publicado na RevistaUsp, n. 48, São Paulo: USP, CCS, dez., jan., fev. 2000-2001.

MOTTER, Maria Lourdes (2003). Ficção e realidade: a construção do cotidiano na telenovela. São Paulo: Alexa Cultural, Comunicação \& Cultura, 2003.

MOTTER, L.M. e JAKUBASZKO. Daniela. Telenovela e realidade social: algumas possibilidades dialógicas. Revista Comunicação \& Educação - Ano XII - N.1 - jan./abr. 2007. p. 55-64.

MOULIN, Carolina. Os direitos humanos dos humanos sem direitos: refugiados e a política do protesto. Rev. bras. Ci. Soc. [online]. 2011, vol.26, n.76, pp.145-155. ISSN 0102-6909. Disponível em http://dx.doi.org/10.1590/S0102-69092011000200008. Disponível em: <http:// www.scielo.br/scielo.php?script=sci_arttext\&pid=S0102-69092011000200008\&lang=en Acesso em: 10 de nov. de 2019.

O ATAQUE a um restaurante palestino em São Paulo. Nexo, São Paulo, 02 de set. de 2019. Disponível em https://www.nexojornal.com.br/expresso/2019/09/02/O-ataque-a-um-restaurante-palestino-em-S\%C3\%A30-Paulo Acesso em: 10 de dez de 2019.

ONU. (1951), Convention relating to the status of refugees, 28 julho 1951. United Nations, Treaty Series, vol. 189, p. 137. Disponível em http://www.unhcr.org/refworld/docid/3be01b964.html Acesso em: 24 de nov de 2019.

'ÓRFÃOS DA TERRA' GANHA principal troféu do seoul drama awards, premiação da tv sul-coreana. Site G1, 15.09.2020. Disponível https://g1.globo.com/pop-arte/noticia/2020/09/15/ orfaos-da-terra-ganha-principal-trofeu-do-seoul-drama-awards-premiacao-da-tv-sul-coreana.ghtml Acesso em 15.09.2020.

'ÓRFÃOS DA TERRA' VENCE premio rose dór em londres. Site G1, 01.12. 2019. Disponível em https://g1.globo.com/pop-arte/noticia/2019/12/01/orfaos-da-terra-vence-premio-rose-dor-em-londres.ghtml Acesso em 02.02.2020

'ÓRFÃOS DA TERRA', PRÓXIMA NOVELA das 18h, terá reprodução de campo de refugiados. Site G1, 06.03.2019. Disponível em https://g1.globo.com/pop-arte/noticia/2019/03/06/ orfaos-da-terra-proxima-novela-das-18h-tera-reproducao-de-campo-de-refugiados.ghtml Acesso em 02.02.2020

'ÓRFÃOS DA TERRA' GANHA prêmio de melhor telenovela no Rose d'Or Awards. Gshow, 1 dez. 2019. Disponível em: https://gshow.globo.com/novelas/orfaos-da-terra/noticia/orfaos-da-terra-ganha-premio-de-melhor-telenovela-no-rose-dor-awards.ghtml Acesso em: 20 jun. 2020. 


\section{Daniela Jakubaszko}

Doutora e Mestre em Ciências da Comunicação (ECA-USP) e graduada em Linguística e Português (FFLCH-USP) é professora dos cursos de comunicação da Escola da Indústria Criativa (ECRIA) da Universidade São Caetano do Sul (USCS) desde 2013, membro de pesquisa do GELiDis (ECA-USP) e do Grupo de Memórias do $A B C$ do Laboratório Hipermídias de Comunicações Culturais (USCS).

E-mail: daniela.jakubaszko@prof.uscs.edu.br

\section{Anna Carolina Cicilini}

Graduanda em Jornalismo na Universidade Municipal de São Caetano do Sul. Project assistant na Wiki Movimento Brasil. E-mail: anna.cicilini@alu.uscs.edu.br

\section{Letícia Gouveia Veras}

Graduanda em Jornalismo na Universidade Municipal de São Caetano do Sul. Estagiária no Sesc Santo André.

E-mail:anna.cicilini@alu.uscs.edu.br 